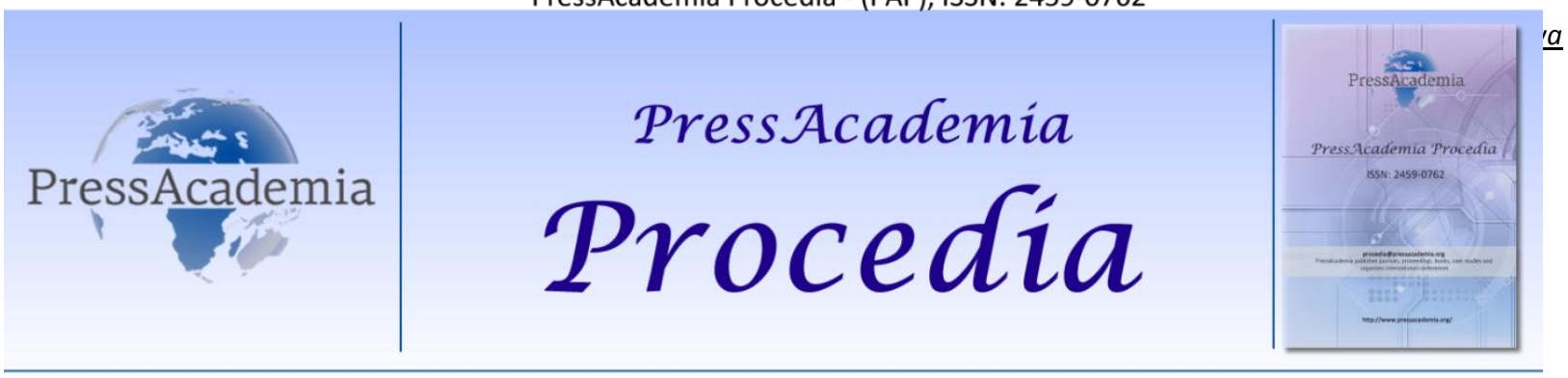

2nd World Conference on Technology, Innovation and Entrepreneurship,

May 12-14, 2017, Istanbul, Turkey.Edited by Sefer Şener

\title{
EFFECT OF HUMAN CAPITAL ON ORGANIZATIONAL PERFORMANCE IN HEALTHCARE ORGANIZATIONS
}

\section{DOI: 10.17261/Pressacademia.2017.513 \\ PAP-WCTIE-V.4-2017(5)-p.34-38}

\author{
Serkan Deniz ${ }^{1}$, Mesut Cimen ${ }^{2}$, Ozlem Atan ${ }^{3}$, Seyit Kaya ${ }^{4}$ \\ ${ }^{1}$ Yalova University, serkand100@gmail.com \\ ${ }^{2}$ Acıbadem University, mesut.cimen@acibadem.edu.tr \\ ${ }^{3}$ Haliç University, ozlematan@ @alic.edu.tr \\ ${ }^{4}$ Haliç University, seyit.kaya@gmail.com
}

\begin{abstract}
For today's competitive environment, organizations are required to increase their performance continuously in order to survive. Human capital is one of the most important aspects, which increases performance. In this study, the influence of human capital on organizational performance is examined. The study was conducted between November 2016 and January 2017 in private healthcare organizations operating in Istanbul. The sample includes the managers working in healthcare organizations. According to the findings, it is founded that there is a positive but low correlation between human capital and organizational performance. Similarly, according to the managers, human capital influences organizational performance in a positive way, however its affect is relatively low. Depending on these results, it is concluded that managers' awareness related to human capital is not sufficient, and increasing these awareness in further studies is recommended.
\end{abstract}

Keywords: Human capital, performance, organizational performance, health, healthcare organizations JEL Codes: M10, 034

\section{INTRODUCTION}

By globalization, important developments in business world have been occurred, and businesses have started to face with an intensively competitive environment. Today, organizations are dealing with issues of increasing market share, satisficing customer expectations, competing, reducing costs, and operating with low profitability. Therefore, taking these efforts into account, it is possible to argue that increasing organizational performance becomes one of the most important conditions of organizational survival. Organizations, who increase their performance, can obtain competitive advantage, and achieve their goals more easily. One the most important determinants of organizational performance is human capital.

Human capital constitutes the most important part of competitive advantage for most organizations, and it has an important influence on organizational success, performance, and efficiency (Yen, 2013). Human capital also has an important role on healthcare organizations in order to survive, increase performance, and obtain competitive advantage. In this study, it is aimed to reveal the influence of human capital on organizational performance in healthcare organizations.

\section{LITERATURE REVIEW}

\subsection{Human Capital}

Human capital refers to the knowledge level, skills, and abilities of the employees in an organization, and it is the main starting point of innovation process (Özaydın, İlhan and Bayrak, 2015). Human capital is one of the most important and valuable assets of an organization, and organizations may achieve important benefits through human capital. Moreover, human capital also helps organizations to become more effective and efficient, and reach organizational goals (Awan and Sarfraz, 2013). 
Today, organizations aim to get competitive advantage are using their employees as a competitive instrument. Increasing employee productivity to get higher value and efficiency has become an important and remarkable strategy. Organizations aim to optimize their workforce not only to achieve their organizational goals, but also to execute long-term plans and to achieve sustainability. As a result, organizations apply human capital development programs in order to optimize their workforce. Therefore, organizations are inclined to invest human capital in order to transform and develop their employees to a workforce with appropriate knowledge, skills, and abilities required for highly changing and complex environment. (Marimuthu, Arokiasamy and Ismail, 2009).

\subsection{Human Capital and Organizational Performance Relationship}

Today, business world emphasizes the importance of organizational performance. There are numerous ways of determining organizational performance (Zehir, Can and Karaboga, 2015). These criteria are classified as financial and non-financial performance measures. Financial performance criteria include profitability, total sales volume, return on investment, and they have been used for long time in organizational performance measurement. However, these criteria are criticized by authors due to their certain shortcomings, such as not completely reflecting the performance. Therefore, organizations, in addition to financial criteria, also use non-financial indicators such as product quality, customer and employee satisfaction, and innovation (Erdem, Gökdeniz and Met, 2011).

Human capital influences organizational performance positively, and provides competitive advantage through increasing organizational performance. Human capital investments have become important parts of organizational performance increasing methods (Marimuthu, Arokiasamy and Ismail, 2009). According to the studies, there is a positive relationship between human capital and organizational performance. For instance, Sharbati, Jawad, and Bontis (2010) found a positive relationship between human capital and organizational performance. Moreover, Crook et al. (2011) suggest that human capital positively influences organizational performance. Drawing on the literature reviewed and the empirical studies above, the following hypotheses are developed:

H1: There is a positive relationship between human capital and organizational performance.

H2: Human capital influences organizational performance positively.

\section{DATA AND METHODOLOGY}

The study was done between November 2016 and January 2017 in private healthcare organizations operating in Istanbul. The sample of the study involves the managers working in these organizations. Data were collected through using surveys, and 102 survey forms were collected. The survey used in the study has three parts. First part is based on demographic information. Second part is based on determining managers' perception about human capital structure in their organization. In the development of the second part, we relied on the studies done by Topaloğlu and Bayrakdaroğlu (2012) and Yıldız (2011). Third part is based on determining managers' perception about organizations' performance. In the development of this part, we relied on the studies done by Küçük and Kocaman (2014), and Zerenler (2005). Statements in the survey are based on 5-point Likert scale (Totally Disagree, Disagree, Neither Agree nor Disagree, Agree, Totally Agree).

In the data analysis process, descriptive statistics were calculated. In determining construct validity of human capital and organizational performance scales, Exploratory Factor Analysis (EFA), and Confirmatory Factor Analysis (CFA) were used. Moreover, fit indices were calculated as well. In order to determine the reliability of the scale, Cronbach's Alpha coefficient was calculated. In addition, Pearson correlation and regression analyses were used to determine the relationship between human capital and organizational performance. The results were evaluated in 95 percent confidence interval, and 5 percent significance level.

\section{FINDINGS AND DISCUSSIONS}

53 ( 52 percent) of the managers participated in the study are lower-level managers, 36 are middle level managers ( 35.3 percent), 13 (12.7 percent) are top managers. 20 (19.6 percent) of them are working for 1-3 years in their organization, 25 (24.5 percent) are working for 4-6 years, 19 (18.6 percent) of them are working for 7-9 years, and 38 (37.3 percent) are working for 10 or more years in their organizations.

Table1: Exploratory Factor Analysis about Human Capital

\begin{tabular}{lc}
\hline Items & $\begin{array}{c}\text { Factor } \\
\text { Loadings }\end{array}$ \\
\hline HC3.Employees are eager for teamwork. & .80 \\
HC4. Employees feel that they belong to the organization, and their commitment is high. & .76 \\
HC2. Employees use their time efficiently, and show high performance. & .76
\end{tabular}


HC6. Employees don't avoid taking risks to succeed .70

HC5. Employees are willing to share their knowledge and abilities with their peers. $\quad .70$

HC7. There is an effective communication between managers and employees.

HC1. Each employee has unique knowledge, in addition to being creative and innovative. $\quad .63$

$\mathrm{KMO}$ and Bartlett tests were applied to determine the appropriateness of data set. KMO score was found to be 0.83 , and Bartlett test was found to be significant $(p<0.01)$. Findings of the exploratory factor analysis are given in Table 1. After factor analysis, statements were grouped under a single factor with seven statements, which explains 51.62 percent of the total variance.

Figure 1: Confirmatory Factor Analysis on Human Capital



Confirmatory factor analysis is done in order to evaluate whether the 7-items structure of the human capital is confirmed or not. The obtained model is given in Figure 1. Fit indices are found to be as CMIN/df=1.64, NFI=0.92, IFI=0.97, TLI=0.94, $\mathrm{CFI}=0.97, \mathrm{RMSEA}=0.08$. According to these results, it is concluded that the fit indices are sufficient. Cronbach's Alpha coefficient, which is calculated to determine reliability of the scale, is found to be as 0.84 , which indicates that internal reliability of the scale is high.

Table 2: Exploratory Factor Analysis about Organizational Performance

\begin{tabular}{lc}
\hline Items & $\begin{array}{c}\text { Factor } \\
\text { Loadings }\end{array}$ \\
\hline OP6. Our organization has a higher level of goal achievement & .88 \\
OP4. Market share of our organization is high. & .78 \\
OP2. Quality of our products and services are high. & .77 \\
OP5. Our organization has high level of efficiency. & .75 \\
OP8. Our organization has high level of profit. & .74 \\
OP3. Our organization has a higher level of success related to developing & .73 \\
new products and services. & .72 \\
OP7. Our organization has a high sales volume. & .60 \\
\hline OP1. Our organization has a higher level of patient satisfaction level. & \\
\hline
\end{tabular}

$\mathrm{KMO}$ and Bartlett tests were applied to determine the appropriateness of data set. KMO score was found to be as 0.89 , and Bartlett test was found to be significant $(p<0.01)$. Findings of the exploratory factor analysis are given in Table 2. Depending on the results of factor analysis, statements were grouped under a single factor with eight statements, which explains 56.05 percent of the total variance. 
Figure 2: Confirmatory Factor Analysis on Organizational Performance



Confirmatory factor analysis is done in order to evaluate whether the 8-items structure of the human capital is confirmed or not. The obtained model is given in Figure 2. Fit indices are found to be as $\mathrm{CMIN} / \mathrm{df}=1.55, \mathrm{NFI}=0.93, \mathrm{IFI}=0.97, \mathrm{TLI}=0.96$, $\mathrm{CFI}=0.97$, RMSEA=0.07. According to these results, it is concluded that the fit indices are sufficient. Cronbach's Alpha coefficient, which is calculated to determine reliability of the scale, is found to be as 0.88 , which indicates that internal reliability of the scale is high.

Table 3: Correlation Analysis

\begin{tabular}{|ll|c|}
\hline & & Human Capital \\
\hline \multirow{3}{*}{ Organizational Performance } & Pearson Correlation & $.208^{*}$ \\
& Sig. (2-tailed) & .036 \\
& $\mathrm{~N}$ & 102 \\
\hline
\end{tabular}

*. Correlation is significant at the 0.05 level (2-tailed).

According to the correlation analysis given in Table $3^{\prime}$, there is a significant and positive, but low relationship between human capital and organizational performance $(r=0.208)$.

Table 4: Influence of Human Capital on Organizational Performance

\begin{tabular}{|l|l|c|c|}
\hline \multirow{2}{*}{ Independent Variable } & Unstandardized Coefficients & \multirow{2}{*}{$\mathbf{t}$} & \multirow{2}{*}{ Sig. } \\
\cline { 2 - 3 } & $\mathbf{B}$ & & \\
\hline (Constant) & 3.99 & 15.68 & .000 \\
Human Capital & 0.16 & 2.13 & .036 \\
\hline & $\mathrm{R}^{2}=0.043$ & & \\
& $\mathrm{~F}=4.52$ & & \\
& Sig. $=0.036$ & & \\
\end{tabular}

Dependent Variable: Organizational Performance

According to the regression analysis given in Table 4, human capital influences organizational performance both positively and significantly $(\beta=0.16, t=2.13, F=4.52, p<0.05)$. 4.3 percent of the variance in organizational performance is explained by human capital $\left(R^{2}=0.043\right)$. These results indicate that human capital is an antecedent of organizational performance, however its determining magnitude is low. 
When Table 3 and Table 4 are examined, it is seen that hypotheses $\mathrm{H} 1$ and $\mathrm{H} 2$ are accepted. According to the results, it was found that there is a positive but low relationship between human capital and organizational performance. Similarly, it is concluded that human capital affects organizational performance positively, whereas its effect is low. This situation can be explained with managers' lack of awareness related to the importance of human capital. However, in another study done in different sector, the relationship between human capital and organizational performance was found to be both positive and higher. Moreover, the influence of human capital on organizational performance was also be found higher in that study (Samad, 2013).

\section{CONCLUSION}

Intense competition within the healthcare sector, cost pressures, and increase in the expectations of patients have been forcing healthcare organizations to increase their performance. Together with highly skilled employees, investments on human capital, which is an antecedent of organizational performance, will increase organizational performance. Therefore, healthcare organizations, which are labor-intensive businesses, are required to perform appropriate and effective plans on human capital. Moreover, managers' awareness and perceptions about human capital must be increased as well. One limitation of this study is that it has a limited sample. However, this study has significance in terms of demonstrating the importance of human capital, and its relationship with organizational performance. For further studies, including higher sample sizes is recommended.

\section{REFERENCES}

Awan, M.A.S., Sarfraz, N. 2013, "The Impact of Human Capital on Company Performance and the Mediating Effect of Employee's Satisfaction", IOSR Journal of Business and Management, Vol.8, Issue.2, pp.76-82.

Crook, T.R., Todd, S.Y., Combs, J.G., Woehr, D.J., Ketchen Jr, D.J. 2011, “Does Human Capital Matter? A Meta-Analysis of the Relationship Between Human Capital and Firm Performance", Journal of Applied Psychology, Vol.96, No.3, pp.443-456.

Erdem, B., Gökdeniz, A., Met, Ö. 2011, "The Relationship Between Innovation and Organizational Performance: A Research in Five-Star Hotels in Antalya", Dokuz Eylul University Faculty of Economics and Administrative Sciences Journal, Vol.26, No.2, pp.77-112.

Küçük, O., Kocaman, G. 2014, "The Relationship between Customer Orientation, Innovation Orientation and Business Performance: An Implementation", The Journal of Academic Social Science Studies, Number: 29 , pp. 37-52.

Marimuthu, M., Arokiasamy, L., Ismail, M. 2009, “Human Capital Development and Its Impact on Firm Performance: Evidence from Developmental Economics", The Journal of International Social Research, Vol. 2/8, pp.265-272.

Özaydın, M.M., İlhan, E., Bayrak, M.R. 2015, “An Alternative Approach to Permanent Improvement of Intellectual Capital and Human Resources: Investors in People (IIP)", Journal of Yasar University, 10/40, pp. 6645-6659.

Samad, S. 2013, "Assessing the Contribution of Human Capital on Business Performance", International Journal of Trade, Economics and Finance, Vol. 4, No. 6, pp.393-397.

Sharabati, A.A.A, Jawad, S.N, Bontis, N. 2010, "Intellectual Capital and Business Performance in The Pharmaceutical Sector of Jordan", Management Decision, Vol. 48, No. 1, pp.105-131.

Topaloğlu, E.E, Bayrakdaroğlu, A. 2012, "The Effects of Intellectual Capital on the Turkish Banking Sector and A Research on this Issue", Electronic Journal of Social Sciences, Volume:11, Issue:41, pp.332-352.

Yen, Y.F. 2013, “The Impact of Bank's Human Capital on Organizational Performance: How Innovation Influences Performance", Innovation: Management, Policy \& Practice, Vol.15, Issue.1, pp.112-127.

Yıldız, S. 2011, "The Effect of Intellectual Capital on Business Performance: A Research in Banking Sector", Anadolu University Journal of Social Sciences, Vol.11, No.3, pp.11-28.

Zehir, C., Can, E., Karaboga, T. 2015, "Linking Entrepreneurial Orientation to Firm Performance: The Role of Differentiation Strategy and Innovation Performance", Procedia-Social and Behavioral Sciences, 210, pp.358-367.

Zerenler, M. 2005, "The Performance Measurement System Design and A Study on Performance Measurement of Manufacturing Systems", The International Journal of Economic and Social Research, 1, pp.1-36. 